\title{
Therapeutic Perspectives of Molecules from Urtica dioica Extracts for Cancer Treatment
}

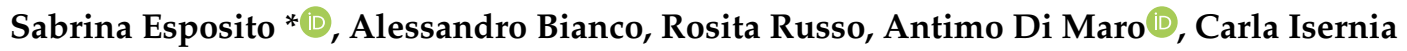 \\ and Paolo Vincenzo Pedone
}

Department of Environmental, Biological, and Pharmaceutical Sciences and Technologies, University of Campania "Luigi Vanvitelli", 81100 Caserta, Italy

* Correspondence: sabrina.esposito@unicampania.it; Tel.: +39-0823-274620

Academic Editor: Derek J. McPhee

Received: 26 June 2019; Accepted: 27 July 2019; Published: 29 July 2019

\begin{abstract}
A large range of chronic and degenerative diseases can be prevented through the use of food products and food bioactives. This study reports the health benefits and biological activities of the Urtica dioica (U. dioica) edible plant, with particular focus on its cancer chemopreventive potential. Numerous studies have attempted to investigate the most efficient anti-cancer therapy with few side effects and high toxicity on cancer cells to overcome the chemoresistance of cancer cells and the adverse effects of current therapies. In this regard, natural products from edible plants have been assessed as sources of anti-cancer agents. In this article, we review current knowledge from studies that have examined the cytotoxic, anti-tumor and anti-metastatic effects of $U$. dioica plant on several human cancers. Special attention has been dedicated to the treatment of breast cancer, the most prevalent cancer among women and one of the main causes of death worldwide. The anti-proliferative and apoptotic effects of $U$. dioica have been demonstrated on different human cancers, investigating the properties of $U$. dioica at cellular and molecular levels. The potent cytotoxicity and anti-cancer activity of the $U$. dioica extracts are due to its bioactive natural products content, including polyphenols which reportedly possess anti-oxidant, anti-mutagenic and anti-proliferative properties. The efficacy of this edible plant to prevent or mitigate human cancers has been demonstrated in laboratory conditions as well as in experimental animal models, paving the way to the development of nutraceuticals for new anti-cancer therapies.
\end{abstract}

Keywords: Urtica dioica; natural products bioactivity; food bioactives; nutraceuticals; cancer therapy; breast cancer

\section{Introduction}

A wide range of chronic and degenerative diseases can be prevented using food product nutraceuticals or functional foods and food bioactive molecules [1,2].

In this context, researchers have studied the Urtica dioica [3,4], an evergreen edible plant commonly used since ancient times in traditional medicine to treat several diseases.

$U$. dioica is the most common species of the Urticaceae family commonly known as Stinging nettle and one of the most studied medicinal plants worldwide. It is an herbaceous perennial plant and has a long history of usage for various kinds of health problems $[3,4]$. The plant grows in tropical and temperate wasteland areas around the world, and well tolerates all environments. The name Urtica comes from the Latin verb urere, namely 'to burn,' attributed to its stinging hairs. The most common species dioica is so defined because the plant generally contains either female or male flowers [5]. The leaves are oval, long petiolate, elongated with toothed margins, the flowers are dioecious, the fruit is a small oval and greenish-yellow achene. The plant has stinging hairs with a tuft of hair at the apex. The leaves and stems contain abundant non-stinging hairs, with touch sensitive tips, needles that will 
inject chemicals including serotonin, histamine, acetylcholine, moroidin, leukotrienes and possibly formic acid into the skin. The irritant compounds provoke pain, wheals or a stinging sensation [6]. However, this edible plant will lose its irritant powers during cooking, the burning property of the juice is, indeed, dissipated by heat and the young shoots may be used for culinary purposes.

The medicinal properties of $U$. dioica are linked to its anti-inflammatory, anti-asthmatic, astringent, depurative, galactogogue, diuretic, nutritive and stimulating effects. The powered leaf's extract has been used as an anti-haemorrhagic agent to reduce excessive menstrual flow and nose bleedings. The roots and herbs are used in different ways: the roots for benign prostate hyperplasia, the herbs for urinary tract disorders and rheumatic conditions, while fresh freeze-dried leaves are used to treat allergies [3,4]. Several studies have also reported its analgesic potential and its role as anti-aggregating factor, as well as describing its favorable effects on cardiovascular and smooth-muscle activity as a hypotensive agent [4]. Indeed, the uses of the plant are extended to different fields including the dye industry, veterinary medicine, the textile industry, cosmeceutics for hair loss lotions and anti-dandruff products and also for culinary usage in the preparation of common dishes [7]. In the popular tradition $U$. dioica leaves are eaten, both raw and blanched, gently fried or steamed in many foodstuffs such as pesto, quiches, soups, purées, sauces, cookies, gelatines and jams. Dried herb is processed for capsules, tablets and teas, and other preparations. Freeze-dried herbs are commonly prepared in capsules. Formulations from fresh plant material include homeopathic products, juice and liquid extracts. Targeted studies favored the reuse of $U$. dioica to produce curd for fresh cheese [8]. The proteins $(3.7 \%)$, dietary fibers $(6.4 \%)$ and low total calories contents $(45.7 \mathrm{kcal} / 100 \mathrm{~g})$ offer $U$. dioica shoots as a nutritional valuable source and a valid contribution in vitamins (A and C), calcium, iron, sodium and fatty acids [9]. Essential fatty acids, such as linoleic and $\alpha$-linolenic acid, account for $20.2 \%$ and $12.4 \%$ of total fatty acids, respectively [10]. Although, the polyunsaturated fatty acids (PUFAs)/saturated fatty acids ratio was reported to be comparably contained, among PUFAs, fatty acids of n- 3 and n- 6 series were more abundant than monounsaturated fatty acids. This finding was in contrast with a recent investigation regarding fatty acids in $U$. dioica leaves which analyzed a rapid solid-liquid extraction (Soxtherm) using petroleum ether as the solvent, revealing a favorable outcome for saturated acids compared to unsaturated acids [11]. Among monounsaturated fatty acids, a small amount of C17:1 fatty acid was detected $(0.13 \%)$. Recently, oxylipins, which are bioactive lipid metabolites derived from PUFAs via cycloxygenase (COX), lipoxygenase and cytochrome P450 pathways, were isolated from a $U$. dioica hydroalcoholic extract [12].

Furthermore, $U$. dioica powder was found to be rich in proteins, three-fold higher than traditional cereals, such as rice, wheat and barley $[9,13]$. U. dioica is also rich in minerals, as is characterized by high levels of calcium $(169 \mathrm{mg} / 100 \mathrm{~g})$ and iron $(277 \mathrm{mg} / 100 \mathrm{~g})$ followed by potassium, phosphorus, magnesium, sodium and zinc. According to reported data, $U$. dioica powder is most likely one of the richest source of minerals among the plant foods. The content of carbohydrate is low (37.4\%) compared to cereals, such as wheat and barley, showing that $U$. dioica powder has a low glycemic index in relation to the conventional sources of plant foods such as cereals and the potato [13].

The benefits of $U$. dioica may be linked to its diversity in secondary metabolites and its content appears to be strongly influenced by the geographic conditions and taxonomical, morphological and genetics factors [14]. In particular, a number of studies have explored and confirmed $U$. dioica as a favorable source of flavonoids and phenylpropanoids [4].

$U$. dioica may be considered as an infesting plant albeit possessing a longstanding history of medicinal usage. Some medicinal capacities of $U$. dioica have been confirmed by modern research and scientific evidences.

The purpose of this review is to focus, among the many biological activities, on the anti-cancer effects of $U$. dioica by examining the cellular and molecular results of $U$. dioica extract treatments on various human cancer cell lines and in-vivo animal models with special attention to breast cancer, the most prevalent cancer among women. 
The study of the mechanisms of action of $U$. dioica may be of importance in the development of food bioactives with natural products for anti-cancer therapies.

PubMed, Scopus and Science Direct were used to consult literature.

\section{Phytochemical Investigations and Biological Activities of Urtica dioica}

The phytochemical composition investigation on $U$. dioica [13-28] revealed that it contains phenolic compounds (including flavonoids, tannins, coumarins and lignans), sterols, fatty acids, polysaccharides and isolectins.

The growing interest in plant phenolic compounds is illustrated by the extensive body of literature devoted to this field of study. Nowadays, it is generally accepted that the therapeutic effects of many plant species are due to the presence of antioxidative phenolics in their tissues. These compounds represent a plant defense mechanism against UV radiation, insects and microorganism, but may also act as plant pigments [29-31].

Phenols and polyphenols in dietary plants have gained considerable attention as therapeutic and prophylactic agents in the treatment of chronic and degenerative diseases [32,33]. In particular, it was observed that all the parts (roots, stalk and leaves) of $U$. dioica are a rich source of these substances and that their content is higher in wild plants than in domesticated plants [18,34]. Root samples from Mediterranean cultivar were reported to contain phenol compounds, such ferulic acid and polyphenols as naringin, ellagic acid, myricetin and rutin (Figure 1). The roots also contained lignans (secoisolariciresinol, 9,90-bisacetyl-neo-olivil and their glucosides), phytosterols (e.g., $\beta$-sitosterol), polysaccharides, isolectins (mainly $U$. dioica agglutinine), coumarins (e.g., scopoletin), simple phenols (e.g., p-hydroxy-benzaldehyde), triterpenoic acids and monoterpendiols.<smiles>COc1cc(/C=C/C(=O)O)ccc1O</smiles>

ferulic acid<smiles>O=c1oc2c(O)c(O)cc3c(=O)oc4c(O)c(O)cc1c4c23</smiles>

ellagic acid<smiles>O=c1c(O)c(-c2cc(O)c(O)c(O)c2)oc2cc(O)cc(O)c12</smiles>

myricetin<smiles>C[C@H]1O[C@H](OC[C@H]2O[C@@H](Oc3cc(O)c4c(c3)OC(c3ccc(O)cc3)CC4=O)[C@H](O)[C@H](O)[C@H]2O)[C@H](O)[C@@H](O)[C@@H]1O</smiles><smiles>C[C@H]1O[C@H](OC[C@H]2O[C@@H](Oc3c(-c4ccc(O)c(O)c4)oc4cc(O)cc(O)c4c3=O)[C@H](O)[C@H](O)[C@H]2O)[C@H](O)[C@@H](O)[C@H]1O</smiles>

Figure 1. Phenolic compounds from $U$. dioica roots.

U. dioica leaves are also constituted by flavonoid glycosides, mainly rutinosyl flavonols, as well as by different depsides of hydroxycinnamic acids with quinic or malic acid (Figure 2). Chlorogenic acid and caffeoyl malic acid represented approximately $76.5 \%$ of total phenolic compounds, whereas rutin was the most abundant flavonol derivative [18,19]. Isorhamnetin-3-O-rutinoside was found, together with rutin, quercetin-3-O-glucoside and kaempferol-3-O-glucoside in methanolic extracts of $U$. dioica leaves and stalks [35]. The polyphenol profile seems to be strongly dependent on the parts of the plant investigated, but also on the harvest site and season. The quantification of $U$. dioica 
phenolics in different extracts, by high-performance liquid chromatography coupled with tandem mass spectrometric detection, evidenced that inflorescence extracts were the richest extracts [17]. Thus, the consumption of $U$. dioica was in line with an amelioration of phenolic compounds food intake and thus, the exploitation of these anti-oxidant and anti-inflammatory compounds defined the plant as a valuable tool towards mutagenesis and carcinogenesis [36].<smiles>[R]Oc1cc(-c2oc3cc(O)cc(O)c3c(=O)c2[R])ccc1O</smiles>

a) $\mathrm{R}=\mathrm{H} \quad \mathrm{R}_{1}=$ glucose

b) $\mathrm{R}=\mathrm{OH} \quad \mathrm{R}_{1}=$ glucose

c) $\mathrm{R}=\mathrm{OH} \quad \mathrm{R}_{1}=$ rutinose

d) $\mathrm{R}=\mathrm{CH}_{3} \quad \mathrm{R}_{1}=$ rutinose<smiles>O=C(/C=C/c1ccc(O)c(O)c1)O[C@H]1C[C@H](C(=O)O)C[C@@H](O)[C@H]1O</smiles>

chlorogenic acid<smiles>O=C(O)CC(OC(=O)/C=C/c1ccc(O)c(O)c1)C(=O)O</smiles>

caffeoyl malic acid



(a) kaempferol-3-O-glucoside;

(b) quercetin-3-O-glucoside; (c) rutin; (d) isorhamnetin-3-O-rutinoside.

Among lipid secondary metabolites, carotenoids were detected in the leaves and their total content was estimated equal to $29.6 \mathrm{mg} / 100 \mathrm{~g}$ dry weight [4,23].

Several studies have established that extracts of $U$. dioica possess various pharmacological effects [37-39], including anti-inflammatory [40-42], anti-oxidant [43-47], anti-microbial [46-49], anti-diabetic [39,50,51], cardiovascular [39], anti-ulcer, analgesic [36], immuno-modulatory [35,52], anti-mutagenic [44] and anti-cancer properties. Moreover, this edible plant has considerable chemopreventive capacities and disease-preventing effects on animals and humans. These health benefits of $U$. dioica may be related to the wide range of bioactive natural products present in the various parts of the plant.

The preventive activity of both polyphenols and carotenoids is associated to the health promoting effects of $U$. dioica against chronic and degenerative diseases such as cancer.

\section{Anticancer Activities of Urtica dioica}

Among the biological activities of $U$. dioica, we report in detail the studies on the anti-cancer effects, due to the induction or inhibition of the key processes in cellular metabolism and the ability to activate the apoptotic pathways. Various studies have recently demonstrated the cytotoxic and anti-cancer properties of $U$. dioica, in particular against colon, gastric, lung, prostate and breast cancers. In this section, we will review the main anti-tumour activities of $U$. dioica demonstrated against several human cancer cell lines and in animal models.

Cancer is a group of diseases in which normal cells grow uncontrollably and abnormally, invade and spread to other parts of the body. Unfortunately, it is a main cause of death worldwide and the incidence and mortality rates are still unacceptably high [53-56]. Notable progresses have been obtained in conventional therapies (as chemotherapy, radiotherapy and surgical excision), but these treatments cause many serious side effects and often may prolong life for only a few years.

Cancer chemoprevention $[57,58]$ has become an important therapeutic option through which the battle against cancer could be possible, using natural, synthetic or biological agents able to reverse, suppress or prevent either carcinogenesis or the progression of premalignant cells towards invasive 
tumors. For this purpose, plants and herbs may be a promising source for adjuvant, complementary or alternative anti-cancer therapy [59-68], since some of them contain bioactive natural products and anti-cancer compounds, including polyphenols [32,33,69,70] as flavonoids, tannin etc. Today, many phytochemical compounds, normally biosynthesized and accumulated in the plants, have shown chemopreventive actions and several anti-cancer drugs, including podophilotoxins, camptotoxins, taxans, arise from herbal compounds and are successfully used for anti-cancer therapy [63,71]. Chemoprevention due to the natural plant-based bioactivity can be achieved through different biochemical and molecular mechanisms involved in cancer control and development. The plants, indeed, contain a number of bioactive molecules that are able to induce cellular protection and responses to stresses, such as anti-oxidant enzymes, apoptosis and/or cell cycle arrest [72,73].

The anti-mutagenic activity of a protein fraction from the aerial parts of $U$. dioica was demonstrated, via the Ames test in various bacteria strains, against the mutagen 2-aminoanthracene; the anti-mutagenic activity can be due to the inhibition of CYP450-isoenzymes, involved in the 2-aminoanthracene mutagen bioactivation [44].

The anti-oxidant and radical scavenging activities of $U$. dioica were reported by ABTS and superoxide-radical scavenger assays and on analysis of the changes in antioxidant enzymes [43-47]. In mice, the treatment with $U$. dioica methanolic extract from the aerial parts demonstrated hepatoprotective and nephroprotective activities against cisplatin-induced [74,75] toxicity, most likely due to increasing antioxidant defense mechanisms, in fact, this extract has been shown to increase the activities of catalase (CAT) and superoxide dismutase (SOD) enzymes and the content of glutathione (GSH) [76]. These activities may be attributed to the flavonoid content of $U$. dioica, in fact, the flavonoids were associated to anti-oxidant and radical scavenging activities [77-79].

The reactive oxygen metabolites have a well-known role in cancer pathogenesis [80,81]. The oxidative stress, with the loss of cellular redox homeostasis and elevated levels of oxygen free radicals, causes the production of mutagenic agents and can be tumorigenic, with a key role in initiation and progression of cancer [82]. Due to the presence of large quantities of compounds with anti-oxidant and free radical scavenger properties, $U$. dioica, and specifically the leaves, are able to reduce the high level of oxidative stress present in cancerous cells and exert a chemopreventive function.

Most drugs in use for cancer treatment are cytotoxic and/or cytostatic [83]. Since the rate of apoptosis was reduced during cancer in several studies, an efficient cancer treatment requires the induction of apoptosis in cancer cells, with the programmed cell death of cancerous and damaged cells, without destructive adverse effects in normal dividing cells [84]. Furthermore one of the more significant properties analyzed in putative cytotoxic anti-tumor agents is the ability to induce apoptosis and/or cell cycle arrest. The cytotoxic activity of $U$. dioica was widely tested by in vitro MTT assay and trypan blue viability exclusion dye assay (to evaluate the number of live cells). The cellular and molecular mechanisms of toxicity were analyzed using different assays. The most commonly used were DNA fragmentation assay and TUNEL test (to detect the type of cell death, apoptosis or necrosis), quantitative Real-Time PCR (qRT-PCR, to quantify the apoptosis- and metastasis- related mRNA expression levels), Western Blotting (to quantify apoptosis-related protein levels) and flow cytometry (to analyze cell cycle distribution and apoptosis). The Tables 1, 2 and 4 (Table 4 is included in the next paragraph) summarize the main findings regarding the anti-cancer properties of $U$. dioica with the plant extracts and parts used (specifying collection sites and the biologically active molecules identified), the cancer cell lines/tissues or animal models tested, the IC50 (concentration required for $50 \%$ inhibition) and the effects. The studies (first author and date) are chronologically listed for various tumoral groups. The studies on benign prostatic hyperplasia are also reported. 
Table 1. Anti-cancer activities of $U$. dioica: cervical, epidermoid, colon, gastric and lung cancer.

\begin{tabular}{|c|c|c|c|c|}
\hline U. dioica Extracts * & Cancer Cell Lines & IC50 & Effects & References \\
\hline $\begin{array}{l}\text { U. dioica L. (Germany) roots aqueous } \\
\text { extract } \\
\text { U. dioica agglutinine (UDA) }\end{array}$ & $\begin{array}{l}\text { HeLa human cervical cancer } \\
\text { A431 human epidermoid carcinoma }\end{array}$ & $\begin{array}{c}5 \mu \mathrm{g} / \mathrm{mL} \\
(24 \mathrm{~h} \text { treatment) } \\
21 \mu \mathrm{g} / \mathrm{mL} \\
\text { (24 h treatment) }\end{array}$ & $\begin{array}{l}\downarrow \text { Proliferation } \\
\downarrow \text { EGF binding }\end{array}$ & Wagner 1994 [85] \\
\hline $\begin{array}{l}\text { U. dioica L. (Iran) roots ethanolic } \\
\text { extract }\end{array}$ & $\begin{array}{l}\text { HT29 human colon cancer } \\
\text { MKN45 human gastric cancer }\end{array}$ & $\begin{array}{c}24.7 \mu \mathrm{g} / \mathrm{mL} \\
(72 \mathrm{~h} \text { treatment }) \\
249.9 \mu \mathrm{g} / \mathrm{mL} \\
(72 \mathrm{~h} \text { treatment })\end{array}$ & $\begin{array}{l}\downarrow \text { Proliferation } \\
\uparrow \text { Apoptosis }\end{array}$ & Ghasemi 2016 [86] \\
\hline $\begin{array}{l}\text { U. dioica L. (Iran) aerial parts } \\
\text { dichloromethane extract }\end{array}$ & HCT-116 human colon cancer & $\begin{array}{c}23.61 \mu \mathrm{g} / \mathrm{mL} \\
(48 \mathrm{~h} \text { treatment })\end{array}$ & $\begin{array}{l}\downarrow \text { Proliferation } \\
\uparrow \text { Apoptosis } \\
\text { G2/M arrest }\end{array}$ & Mohammadi 2016 [87] \\
\hline $\begin{array}{l}\text { U. dioica L. (Italy) leaves methanolic } \\
\text { extract, oxylipins }\end{array}$ & $\begin{array}{l}\text { NSCLC H1299 human non-small cell } \\
\text { lung cancer } \\
\text { NSCLC A549 human non-small cell } \\
\text { lung cancer }\end{array}$ & $\begin{array}{c}52.3 \mu \mathrm{g} / \mathrm{mL} \\
(72 \mathrm{~h} \text { treatment }) \\
47.5 \mu \mathrm{g} / \mathrm{mL} \\
(72 \mathrm{~h} \text { treatment })\end{array}$ & $\begin{array}{c}\downarrow \text { Proliferation } \\
\uparrow \text { Apoptosis extrinsic pathway } \\
\uparrow \text { caspase } 3 \uparrow \text { caspase } 8 \\
\uparrow \text { cPARP } \uparrow \text { tBid } \\
\uparrow \text { GADD } 153 \uparrow \text { DR5 G2/M arrest }\end{array}$ & D’Abrosca 2019 [12] \\
\hline
\end{tabular}

* The plant extracts and parts used with specified collection sites and the biologically active molecules identified. 
Table 2. Anti-cancer effects of $U$. dioica: prostate cancer, in-vitro and in-vivo studies.

\begin{tabular}{|c|c|c|c|c|}
\hline U. dioica Extracts * & $\begin{array}{c}\text { Cancer Cell Lines/Tissues/Animal } \\
\text { Models }\end{array}$ & IC50 & Effects & References \\
\hline $\begin{array}{l}\text { U. dioica L.(Germany) roots } \\
\text { methanolic extract }\end{array}$ & $\begin{array}{c}\text { Balb/c mouse model of benign prostatic } \\
\text { hyperplasia ( } 28 \text { days, } 5 \mathrm{mg} \text { oral } \\
\text { treatment) }\end{array}$ & & $\begin{array}{l}\downarrow \text { hyperplasia } 51.4 \% \text { growth } \\
\text { inhibition }\end{array}$ & Lichius 1997 [88] \\
\hline $\begin{array}{l}\text { U. dioica L.(Germany) roots } \\
\text { methanolic extract }\end{array}$ & LNCaP human prostate cancer & & $\begin{array}{l}\downarrow \text { Proliferation } 30 \% \text { ( } 5 \text { day } \\
\text { treatment with } 1 \mu \mathrm{g} / \mathrm{mL})\end{array}$ & Konrad 2000 [89] \\
\hline$U$. dioica $L$. leaves aqueous extract & $\begin{array}{l}\text { prostate tissue from prostate cancer } \\
\text { patients }\end{array}$ & $\begin{array}{c}50 \mu \mathrm{g} / \mathrm{mL} \\
\text { (30 min treatment) }\end{array}$ & $\downarrow \mathrm{ADA}$ & Durak 2004 [90] \\
\hline $\begin{array}{l}\text { U. dioica L. (India) roots petroleum } \\
\text { ether extract, } \beta \text {-sitosterol } \\
\text { roots ethanolic extract, } \beta \text {-sitosterol } \\
\text { and scopoletin }\end{array}$ & $\begin{array}{c}\text { rat model of benign prostatic } \\
\text { hyperplasia ( } 28 \text { days, } 50 \mathrm{mg} / \mathrm{Kg} \text { oral } \\
\text { treatment) }\end{array}$ & $\begin{array}{c}0.19 \mathrm{mg} / \mathrm{mL} \\
\text { (28 day treatment) } \\
0.12 \mathrm{mg} / \mathrm{mL} \\
\text { (28 day treatment) }\end{array}$ & $\downarrow$ hyperplasia $\downarrow 5 \alpha$-reductase & Nahata 2012 [91] \\
\hline $\begin{array}{l}\text { U. dioica L. (Iran) leaves } \\
\text { dichloromethane extract }\end{array}$ & PC3 human prostate cancer & $\begin{array}{c}15.54 \mu \mathrm{g} / \mathrm{mL} \\
(48 \mathrm{~h} \text { treatment })\end{array}$ & $\begin{array}{c}\downarrow \text { Proliferation } \\
\uparrow \text { Apoptosis intrinsic pathway } \\
\uparrow \text { caspase } 3 \uparrow \text { caspase } 9 \\
\downarrow \text { Bcl-2 } \\
\text { G2/M arrest }\end{array}$ & Mohammadi 2016 [92] \\
\hline
\end{tabular}

* The plant extracts and parts used with specified collection sites and the biologically active molecules identified. ADA: adenosine deaminase. 
In the study by Ghasemi et al. (2016) [86] the cytotoxic effects of an ethanolic extract of $U$. dioica roots $(0-2000 \mu \mathrm{g} / \mathrm{mL}$ ) were demonstrated on human colon (HT29) and gastric (MKN45) cancer cells. Cells were treated with increasing concentrations of $U$. dioica for 24-72 h. $U$. dioica decreased cell viability in a dose- and time- dependent manner, with IC50 values of 24.7 and $249.9 \mu \mathrm{g} / \mathrm{mL}$, respectively, after $72 \mathrm{~h}$ exposure. In addition, $U$. dioica treatment induced apoptotic cell death, as shown by flow cytometry analysis. The different studied cell lines showed a diverse sensitivity to the $U$. dioica treatment, with more sensitive human colon cancer HT29 cells compared to human gastric cancer MKN45 cells, a cell line poorly differentiated and usually resistant to chemotherapy. Interestingly, the anti-proliferative effects of $U$. dioica treatments are comparable to those obtained with oxaliplatin, a current anti-neoplastic drug. In line with these findings, Mohammadi et al. (2016) [87], demonstrated the cytotoxic effects of a dichloromethane extract of $U$. dioica aerial parts plant on human colon cancer cell line HCT-116, with IC50 of $23.61 \mu \mathrm{g} / \mathrm{mL}$ ( $48 \mathrm{~h}$ treatment) and by eliciting apoptotic cell death and arresting the cell cycle at the G2/M phase.

The dichloromethane extract of $U$. dioica leaves inhibited the growth and proliferation of human prostate cancer cells (PC3), showing a IC50 concentration of $15.54 \mu \mathrm{g} / \mathrm{mL}$ in $48 \mathrm{~h}$ exposure and a cell cycle arrest in G2/M phase (Mohammadi et al. 2016) [92]. In this study, the observed increased expression levels of pro-apoptotic genes caspase 3 and 9 and reduced anti-apoptotic Bcl-2 suggested that cytotoxicity was due to apoptosis induction from intrinsic (mitochondrial) pathway. Moreover, a methanolic extract of $U$. dioica roots previously produced a significant dose- and time- dependent reduction in proliferation of human prostate carcinoma cells (LNCaP), with a 30\% maximum growth inhibition after 5 day exposure with $1 \mu \mathrm{g} / \mathrm{mL}$ extract concentration (Konrad et al. 2000) [89].

More recently, D'Abrosca et al. (2019) [12] reported the effects of $U$. dioica leaves methanolic extract against the human non-small cell lung cancer cell lines (NSCLC). Exposure of H1299 and A549 NSCLC cells to this extract inhibited cell proliferation, with an IC50 of 52.3 and $47.5 \mu \mathrm{g} / \mathrm{mL}$, respectively. NSCLC cells have a low sensitivity to cisplatin $[74,75,93]$, a cytotoxic agent largely utilized for chemotherapy cancer cure. The co-treatment with the $U$. dioica extract and cisplatin ameliorated the cisplatin cytotoxicity, thus showing a synergistic effect. U. dioica extract induced arrest at G2/M cell cycle phase and apoptosis from extrinsic pathway, as demonstrated by the observed decreased levels of pro-caspase 3 and pro-caspase 8 proteins (indicating the activation and increasing of the apoptotic proteolytic enzymes caspase 3 and caspase 8 ) and increased levels of cPARP and tBid (substrates of caspase 3 and caspase 8, respectively). GADD153 (a marker of endoplasmic reticulum stress) [94-96] and DR5 (death receptor [97] a cell surface receptor of the TNF-receptor superfamily, which directly promotes the extrinsic apoptotic pathway) were also upregulated after U. dioica treatment, confirming that the extracts promoted the extrinsic apoptotic pathway. Interestingly, rutin and oxylipins (polyunsaturated oxidised fatty acids) [98-100] were identified in the U. dioica extract on investigation of the exact mechanism involved in cell death, via spectroscopic techniques NMR $[101,102]$ and mass spectrometry analyses. In particular, oxylipins, including the most abundant 13-S-hydroxy-9Z, 11E, 15Z-octadecantrienoic acid, were proved to be the bioactive natural products responsible for anti-cancer activity (Figure 3 and Table 3). Oxylipins are a large and diverse family of secondary metabolites derived from the oxidation of PUFAs [103]. The oxylipin 13-S-hydroxy-9Z, 11E, 15Z-octadecantrienoic acid also possess anti-inflammatory properties in human chondrocytes [41]. It is noteworthy that a plant oxylipin, 12-oxo-phytodienoic acid, potently suppressed the proliferation of human breast cancer cell lines T47-D and MDA-MB-231, reducing the expression of the cyclin D1 and inducing arrest at G1 phase of the cell cycle [104,105]. In addition, another biologically active molecule of $U$. dioica is a rare lectin (carbohydrate-binding protein), $U$. dioica agglutinine (UDA, accession number P11218 in Protein Data Bank) [106], isolated from the $U$. dioica aqueous roots extract (Wagner et al. 1994) [85]. This molecule demonstrated in vitro anti-proliferative properties on human cervical cancer HeLa cells and human epidermoid carcinoma A431 cancer cells. On HeLa and A431 cells UDA inhibited the binding of EGF to its receptor with an IC50 of 5 and $21 \mu \mathrm{g} / \mathrm{mL}$, respectively, after $24 \mathrm{~h}$ exposure [107]. 
<smiles>COc1cc2ccc(=O)oc2cc1O</smiles><smiles>CC[C@H](CC[C@@H](C)C1CCC2C3CC=C4C[C@@H](O)CCC4(C)C3CCC2(C)C1C)C(C)C</smiles><smiles>C=C/C=C\C[C@H](O)/C=C/C=C/CCCCCCCC(=O)O</smiles>

13-S-hydroxy-9Z, 11E, 15Z-octadecantrienoic acid (oxylipin)

Figure 3. Molecular structures of selected bioactive phytochemicals isolated from $U$. dioica.

Moreover, in-vitro studies and investigations regarding testosterone-induced rat models of prostatic hyperplasia, examined the effects of petroleum ether and ethanolic extracts of the $U$. dioica roots (28 day, $50 \mathrm{mg} / \mathrm{Kg}$, oral treatment), Nahata et al. (2012) [91]. The results demonstrated that $U$. dioica significantly reduced the activity of $5 \alpha$-reductase enzyme and the dimension of the prostatic hyperplasia. $5 \alpha$-reductase [108] is a key enzyme involved in testosterone metabolism, thus in hormone-dependent prostate hyperplasia and prostate cancer. The IC50 values for $5 \alpha$-reductase were of 0.19 and $0.12 \mathrm{mg} / \mathrm{mL}$, respectively, on the $28^{\text {th }}$ day of treatment. In both the extracts, via spectroscopic techniques, the $\beta$-sitosterol was isolated; in ethanolic extract scopoletin was also found (Figure 3 and Table 3). $\beta$-sitosterol is a sterol originated by a complex and multistage biosynthetic process [109]; it was jet reported to treat patients with prostate diseases $[110,111]$. Scopoletin is a courmarin derived by a known biosynthesis pathway [112]; it possesses anti-inflammatory properties [113] and has been reported to induce anti-proliferative and pro-apoptotic effects on the prostate cancer cell line PC3 [114]. In a previous animal study (Lichius et al. 1999) [88], the experimentally induced benign prostatic hyperplasia in Balb/c mouse was reduced, by a methanolic extract of $U$. dioica roots, orally administered for 28 days ( $5 \mathrm{mg}$ ), with an observed $51.4 \%$ growth inhibition.

Table 3. Biological activities of specific molecules isolated from $U$. dioica.

\begin{tabular}{|c|c|c|c|}
\hline Molecules & Biological Activities & Cells & References \\
\hline $\begin{array}{c}\text { 13-S-hydroxy-9Z, 11E, } \\
\text { 15Z-octadecantrienoic acid } \\
\text { (oxylipin) }\end{array}$ & $\begin{array}{l}\text { Anti-proliferation } \\
\text { ro-apoptotis Stop cell } \\
\text { cycle Anti-inflammation }\end{array}$ & $\begin{array}{l}\text { lung cancer } \\
\text { chondrocytes }\end{array}$ & {$[12,41]$} \\
\hline U. dioica agglutinine (UDA) & $\begin{array}{l}\text { Anti-proliferation } \\
\text { Anti-EGF binding }\end{array}$ & $\begin{array}{c}\text { cervical cancer } \\
\text { epidermoid carcinoma }\end{array}$ & {$[85,107]$} \\
\hline$\beta$-sitosterol & $\begin{array}{c}\text { Anti-proliferation } \\
\text { Inhibition } 5 \alpha \text {-reductase }\end{array}$ & prostate & {$[91,110,111]$} \\
\hline scopoletin & $\begin{array}{c}\text { Anti-proliferation } \\
\text { Inhibition } 5 \alpha \text {-reductase } \\
\text { Anti-inflammation } \\
\text { Pro-apoptotis }\end{array}$ & $\begin{array}{c}\text { prostate } \\
\text { prostate cancer }\end{array}$ & {$[91,113,114]$} \\
\hline
\end{tabular}

Figure 3 present the molecular structures of specific biologically active compounds identified from $U$ dioica. Table 3 summarizes the biological activities of specific bioactive molecules isolated from the $U$ dioica extracts in each anti-cancer study. 


\section{Urtica dioica and Breast Cancer}

Breast cancer is the most prevalent cancer among women and one of the main causes of death worldwide. Breast cancer statistics indicate that in the US one woman in eight will suffer from breast cancer and that more than 200,000 new patients with breast cancer will be diagnosed every year $[115,116]$. Tumor invasion and metastasis remain the main causes of patients' mortality and still present an important therapeutic challenge. For the treatment of breast cancer, a multidisciplinary approach is currently used, involving surgery, radiotherapy, chemotherapy, hormone therapy, immunotherapy and other novel treatment strategies such as gene silencing, but they are associated with serious side effects $[56,117,118]$. Various new therapeutic targets for adjuvant, complementary and alternative medicines, including natural products bioactivity from plants, have been proposed by several new studies to treat breast cancer patients $[60,62,119]$.

In this paragraph, we report investigations, via in-vitro studies and animal models, on $U$. dioica as a potential natural source of food bioactives and chemotherapeutic agent for breast cancer (Table 4).

In a study by Fattahi et al. (2013) [45], the activity of $U$. dioica leaves aqueous extract was analyzed on the human breast cancer cell line MCF-7. The $U$. dioica extract demonstrated anti-oxidant and anti-proliferative activity. After 24, 48 and $72 \mathrm{~h}$ of exposure to different concentrations of the $U$. dioica extract, significant cell death was observed in a dose-dependent manner, with an IC50 value of $2 \mathrm{mg} / \mathrm{mL}$ concentration after $72 \mathrm{~h}$ of treatment. In accordance with previous observations regarding anticancer drugs [118], the decrease of cell viability caused by $U$. dioica was due to the induction of apoptosis but not to necrosis. The treatment-induced apoptosis was demonstrated at the cellular level by morphological observation, DNA ladder formation, flow cytometry analysis and at the molecular level by measuring the increased amount of the different apoptotic-related proteins caspase 3, caspase 9, Bax (a pro-apoptotic protein), Bcl-2, calpain 1 (a calcium-dependent cytosolic cysteine protease) and calpastatin (a specific inhibitor of calpain 1). Noteworthy was the increase in the anti-apoptotic Bcl-2 protein; indeed, Bcl-2 can interact with Nur 77/TR3 and convert to Bax-like death effector, subsequently inducing apoptosis [120]. These findings were in agreement with a recent study by Fattahi et al. (2018) [121]. In this study, two human breast cancer cell lines, MCF-7 (estrogen and progesterone receptors positive; wild-type P53) and MDA-MB-231 (estrogen and progesterone receptors negative; mutated P53), were treated with $U$. dioica aqueous extract of leaves. The cytotoxicity of the treatment was confirmed, with IC50 values for both breast cancer cell lines of approximately $2 \mathrm{mg} / \mathrm{mL}$, after $72 \mathrm{~h}$ exposure. U. dioica extract induced the apoptosis and increased the expression levels of Bax, especially in MCF-7 cells. Interestingly, $U$. dioica extract has been shown to influence the gene expression of two other proteins, adenosine deaminase (ADA) [122] and ornithine decarboxylase (ODC1) [123]. The expression level of ADA gene in MCF-7 cell line was increased in a dose-dependent manner, but did not modify in the MDA-MB-231 cell line. Alternatively, the ODC1 gene was upregulated in both cell lines. These enzymes show a regulatory role in cellular processes such as proliferation, cell growth and apoptosis [123,124]. In particular, ADA is a key enzyme in adenosine metabolism and nucleotide DNA turnover; ODC1 is the key enzyme in biosynthesis of polyamines $[125,126]$. Considering that $U$. dioica extracts contain phytoestrogens [127], the differences observed in these two cell lines could be due to a diverse status of hormone receptors. Moreover, it is possible that $U$. dioica in MDA-MB-231 cells may induce apoptosis via a P53-independent pathway. 
Table 4. Anti-cancer effects of $U$. dioica: breast cancer, in-vitro and in-vivo studies.

\begin{tabular}{|c|c|c|c|c|}
\hline U. dioica Extracts * & Cancer Cell Lines/ Animal Models & IC50 & Effects & References \\
\hline $\begin{array}{l}\text { U. dioica L. (Jordan) leaves and stems } \\
\text { ethanol extract }\end{array}$ & MCF-7 human breast cancer & & $\begin{array}{c}\downarrow \text { Proliferation } \\
7 \%(72 \mathrm{~h} \text { treatment with } 50 \\
\mu \mathrm{g} / \mathrm{mL})\end{array}$ & Abu-Dahab 2007 [128] \\
\hline U. dioica, $L$. (Iran) leaves aqueous extract & MCF-7 human breast cancer & $\begin{array}{c}2 \mathrm{mg} / \mathrm{mL} \\
(72 \mathrm{~h} \text { treatment })\end{array}$ & $\begin{array}{c}\downarrow \text { Proliferation } \\
\uparrow \text { Apoptosis intrinsic pathway } \\
\uparrow \text { caspase } 3 \uparrow \text { caspase } 9 \\
\uparrow \text { Bax } \uparrow \text { Bcl-2 } \\
\uparrow \text { calpain } 1 \\
\uparrow \text { calpastatin } \\
\end{array}$ & Fattahi 2013 [45] \\
\hline $\begin{array}{l}\text { U. dioica, L. (Iran) leaves dichloromethane } \\
\text { extract }\end{array}$ & MDA-MB-468 human breast cancer & $\begin{array}{c}15.54 \mu \mathrm{g} / \mathrm{mL} \\
(48 \mathrm{~h} \text { treatment })\end{array}$ & $\begin{array}{c}\downarrow \text { Proliferation } \\
\uparrow \text { Apoptosis intrinsic pathway } \\
\uparrow \text { caspase } 3 \uparrow \text { caspase } 9 \\
\downarrow \text { Bcl-2 } \\
\end{array}$ & Mohammadi 2016 [129] \\
\hline $\begin{array}{l}\text { U. dioica, } L \text {. (Iran) leaves dichloromethane } \\
\text { extract }\end{array}$ & MDA-MB-468 human breast cancer & $\begin{array}{c}0.59 \mu \mathrm{M} \\
\begin{array}{c}\text { (24 h co-treatment paclitaxel + } \\
\text { extract) }\end{array}\end{array}$ & $\begin{array}{c}\downarrow \text { Proliferation } \\
\uparrow \text { Apoptosis } \\
\downarrow \text { Migration } \\
\downarrow \text { Snail-1 } \\
\downarrow \text { ZEB1, ZEB2, twist G2/M arrest } \\
\downarrow \text { Cdc2 } \\
\end{array}$ & Mohammadi 2016 [130] \\
\hline $\begin{array}{l}\text { U. dioica, L. (Iran) leaves dichloromethane } \\
\text { extract }\end{array}$ & $\begin{array}{c}\text { MCF-7 human breast cancer } \\
\text { MDA-MB-231human breast cancer } \\
\text { 4T1 mouse breast cancer } \\
\text { Balb/c mouse model of breast cancer } \\
\text { (28 day, } 20 \mathrm{mg} / \mathrm{Kg} \text { injection treatment) }\end{array}$ & $\begin{array}{c}31.37 \mathrm{mg} / \mathrm{mL} \\
(48 \mathrm{~h} \text { treatment }) \\
38.14 \mathrm{mg} / \mathrm{mL} \\
(48 \mathrm{~h} \text { treatment }) \\
35.21 \mathrm{mg} / \mathrm{mL} \\
(48 \mathrm{~h} \text { treatment })\end{array}$ & $\begin{array}{c}\downarrow \text { Proliferation } \\
\downarrow \text { Migration } \\
\downarrow \text { miR-21 } \\
\downarrow \text { MMP1, MMP9, MMP13, } \\
\text { vimentin, CXCR4 } \\
\uparrow \text { E-cadherin } \\
\end{array}$ & Mansoori 2017 [131] \\
\hline $\begin{array}{l}\text { U. dioica, } L \text {. (Iran) leaves dichloromethane } \\
\text { extract }\end{array}$ & $\begin{array}{l}\text { Balb/c mouse model of breast cancer } \\
\text { ( } 28 \text { day, } 20 \mathrm{mg} / \mathrm{Kg} \text { injection treatment) }\end{array}$ & & $\begin{array}{c}\downarrow \text { Metastasis } \\
\uparrow \text { Apoptosis intrinsic pathway } \\
\uparrow \text { caspase } 3 \uparrow \text { caspase } 9 \\
\downarrow \text { Bcl-2 } \downarrow \text { Ki-67 }\end{array}$ & Mohammadi 2017 [132] \\
\hline U. dioica, aqueous extract & $\begin{array}{l}\text { rat model of breast cancer } \\
(5.5 \text { months, } 50 \mathrm{~g} / \mathrm{kg} \text { food treatment) }\end{array}$ & & $\begin{array}{c}\downarrow \text { Metastasis } \\
\downarrow \text { lipid peroxidation } \\
\uparrow \text { catalase } \\
\end{array}$ & Telo 2017 [133] \\
\hline \multirow[t]{2}{*}{ U. dioica, L. (Iran) leaves aqueous extract } & $\begin{array}{c}\text { MCF-7 } \\
\text { human breast cancer }\end{array}$ & $\begin{array}{c}2 \mathrm{mg} / \mathrm{mL} \\
(72 \mathrm{~h} \text { treatment })\end{array}$ & $\begin{array}{c}\downarrow \text { Proliferation } \\
\uparrow \text { Apoptosis } \\
\uparrow \text { ADA } \\
\uparrow \text { ODC1 } \\
\end{array}$ & \multirow[t]{2}{*}{ Fattahi 2018 [121] } \\
\hline & $\begin{array}{c}\text { MDA-MB-231 } \\
\text { human breast cancer }\end{array}$ & $\begin{array}{c}2 \mathrm{mg} / \mathrm{mL} \\
\text { (72 h treatment) }\end{array}$ & $\begin{array}{c}\downarrow \text { Proliferation } \\
\uparrow \text { Apoptosis = ADA } \\
\uparrow \text { ODC1 }\end{array}$ & \\
\hline
\end{tabular}

* The plant extracts and parts used with specified collection sites. ADA: adenosine deaminase; ODC1: ornithine decarboxylase. 
Furthermore, it is interesting to report that the $U$. dioica leaves aqueous extract in the prostate tissue of patients with prostate cancer, while, inhibited the activity of ADA, with IC50 of about $50 \mu \mathrm{g} / \mathrm{mL}$ (calculated, 30 min treatment) (Durak et al. 2004) [90].

Different modes of actions and effects of the $U$. dioica extracts are then possible in the various cell lines and tissues. Differences in in-vitro conditions related to patient's tissue and cell lines also to be considered.

Mohammadi et al. (2016) [129] in a previous study also demonstrated the cytotoxic and apoptotic effects of a dichloromethane extract of $U$. dioica leaves, in MDA-MB-468 cells, a human breast adenocarcinoma cell line. The dichloromethane extract of $U$. dioica induced a dose- and time-dependent anti-proliferative effect. The IC50 concentrations were of 29.46 and $15.54 \mu \mathrm{g} / \mathrm{mL}$ for 24 and $48 \mathrm{~h}$ exposure, respectively. These experimental values for IC50 demonstrate that the dichloromethane extract of $U$. dioica leaves have a more potent cytotoxic effect, on MDA-MB-468 cells. In this cell line, $U$. dioica dichloromethane extract caused cell death through apoptosis as revealed by morphological changes, TUNEL test, DNA fragmentation ladders and mRNA expression levels of apoptotic-related genes. In particular, $U$. dioica activated apoptosis through the intrinsic pathway, as revealed by the increase in the caspase 3 and caspase 9, the decrease in the Bcl2 and any significant changes in caspase 8 expression levels. Interestingly, Mohammadi et al. (2016) [130] demonstrated a synergic effect on cell death and invasion of human breast cancer MDA-MB-468 cell line, by treatment of $U$. dioica leaves dichloromethane extract in combination with the paclitaxel drug. Paclitaxel is one of the most commonly used natural drugs (derived from the bark of pacific yew tree) approved for chemotherapy in different types of cancers, such as ovary cancer, breast cancer and non-small cell lung cancer, acting as an anti-microtubule chemotherapy drug [134]. The antitumor potency of combinational therapy with paclitaxel and $U$. dioica extract was investigated on the human breast cancer cell line MDA-MB-468, demonstrating that $U$. dioica significantly increased the sensitivity of breast cancer cells to paclitaxel therapy, ameliorating its cytotoxicity. In fact, the MTT test demonstrated, in a time- and dose-dependent manner, a strong reduction of cell viability and of IC50 values for paclitaxel in the co-treatment with $U$. dioica extract: from $6.73 \mu \mathrm{M}$ for paclitaxel alone, to $0.59 \mu \mathrm{M}$ for co-treatment, after $24 \mathrm{~h}$. The synergic effect of $U$. dioica extract and paclitaxel was also demonstrated on cell migration; in fact, by scratch test [135], a decreased invasion rate and a reduced number of migrated cells were observed. The molecular mechanism involved was elucidated studying the synergic effect of $U$. dioica and paclitaxel on the expression of snail-1 and related genes ZEB1, ZEB2 and twist. Snail-1 is a protein involved in invasion and migration of cancer cells [136-138] and is required for metastatic ability in breast cancer [139]; in fact, the silencing of snail-1 gene using specific siRNA prevented the metastasis of breast cancer cells. The observed reduction of the expression of snail- 1 and related genes after the co-treatment was in agreement with its anti-metastatic potential. Moreover, a synergic effect of $U$. dioica and paclitaxel on the cell cycle arrest also revealed cell cycle arrest occurring at the G2/M phase, with a decreased Cdc2 expression. In agreement with these studies, Mansoori et al. (2017) [131], demonstrated that the dichloromethane extract of $U$. dioica leaves significantly decreased the cell proliferation of three different breast cancer cell lines, the human MCF-7 and MDA-MB-231 and mouse 4T1. The observed IC50 concentration of $U$. dioica extract was $31.37 \mathrm{mg} / \mathrm{mL}$ in MCF-7, $38.14 \mathrm{mg} / \mathrm{mL}$ in MDA-MB-231 and $35.21 \mathrm{mg} / \mathrm{mL}$ in $4 \mathrm{~T} 1$ cells, at $48 \mathrm{~h}$ of treatment. Moreover, the scratch assay demonstrated an inhibitory effect of $U$. dioica on the migration of the breast cancer cell lines. Moreover, the authors investigated the signalling pathway by which $U$. dioica could inhibit the cell migration. In detail, demonstrated that $U$. dioica extract could inhibit tumor metastasis by regulating miR-21 (a crucial oncomir that is overexpressed in advanced tumors and metastasis) [140-146], the matrix metalloproteinases [147] MMP1, MMP9, MMP13, the vimentin [148], CXCR4 [149,150] and E-cadherin [151], important metastasis-related genes involved in cellular invasion by modifying adhesion junctions and the migratory capacity of cells [152]. In particular, miR-21, MMP1, MMP9, MMP13, CXCR4 and vimentin were found overexpressed in the invasive margins of breast cancer tissues of clinical samples and in the cancer cell lines; E-Cadherin, on the other hand, was decreased. 
U. dioica extract treatment decreased miR-21 expression, which substantially reduced the overexpressed MMP1, MMP9, MMP13, vimentin and CXCR4, and increased E-cadherin in the treated tumor cell lines. In a previous study (Abu-Dahab and Afifi, 2007) [128] the cytotoxic effects of $U$. dioica ethanol extracts from leaves and stems were tested on human breast cancer cell lines MCF-7 and the percentage of MCF-7 cell survival after 72 hrs exposure to $50 \mu \mathrm{g} / \mathrm{mL}$ extract was $93.12 \%$.

Finally, the $U$. dioica root methanolic extract inhibited, via an in-vitro test, aromatase enzyme activity in a concentration dependent manner [153]. Aromatase is a key enzyme involved in steroid hormone metabolism (mediating the conversion of androgens into estrogens) and is targeted in hormonal therapy of hormone-sensible breast cancers, thus acting on the cancer promotion.

Taken together, the various studies on cell lines demonstrated a diverse sensitivity to the $U$. dioica treatments and the extract tested showed differences in anti-cancer potency. It is important to consider that the cell survival and IC50 discrepancies observed in the various studies could be caused by differences in the habitat and parts of the plant used, in cell line types investigated and in the $U$. dioica extraction process.

The effectiveness of $U$. dioica to treat breast cancer has been proved not only in laboratory conditions but also in in-vivo experimental models.

Mohammadi et al. (2017) [132] prepared an in vivo-induced model of breast cancer, mice Balb/c with allograft tumors caused by injecting subcutaneously $4 \mathrm{~T} 1$ murine breast tumor cells, and then administered $U$. dioica leaves dichloromethane extract ( 10 or $20 \mathrm{mg} / \mathrm{kg}$ body weight) by intraperitoneal injection for 28 days. Interestingly, $U$. dioica extract significantly reduced the tumor masses in the treated mice and significantly diminished the size and weight of the tumors removed from the treated mice. By TUNEL assay, it was shown that the $U$. dioica extract induced apoptosis in Balb/c allograft tumor models. Furthermore, the Ki-67 test demonstrated that the $U$. dioica treatment reduced tumor growth, decreasing the percentage of cell proliferation in the breast cancer tissue. Then, real-time PCR studies revealed that the intraperitoneal injection of $U$. dioica extract into the model mice was able to elicit the intrinsic pathway of apoptosis with increased expression of pro-apoptotic caspase 3 and caspase 9 and a downregulation of anti-apoptotic Bcl2. In the treated mice (4T1-induced Balb/c mouse model of breast cancer), according to the results previously reported on the breast cancer cell lines MCF-7, MDA-MB-231 and 4T1, U. dioica treatment induced the anti-metastatic pathway, with decreased expression of miR-21, MMP1, MMP9, MMP13, vimentin and CXCR4 and increased expression of E-cadherin (Mansoori et al. 2017) [131].

Finally, in an animal study by Telo et al. (2017) [133], the effects of $U$. dioica in $\mathrm{N}$-methyl-N-nitrosourea-induced rat model of breast cancer were investigated. Aqueous extract of $U$. dioica, $50 \mathrm{~g} / \mathrm{kg}$ powdered, was added into the food of rats for 5.5 months. The lipid peroxidation, the antioxidant enzyme activities and the formation of mammary gland cancer was then evaluated. $U$. dioica administration decreased the levels of lipid peroxidation and increased catalase antioxidant enzyme activity in rats generated mammary tumors. The results demonstrated, besides, a reduced rate in formation of breast cancer, with a decreased number of cancer masses.

Each $U$. dioica extract and its effects are identified using different color codes. The dashed arrows denote the results obtained with whole extracts; the solid arrows indicate the specific molecules isolated from the extracts and their effects. A generic picture of apoptosis signalling, indicating where and how molecules or extracts of $U$. dioica act on the different cellular targets, is included. By different images are specified if these results were observed in-vitro or in-vivo, on specific cancer types.

In Figure 4 we summarize the main anti-cancer studies and results reported for the various U. dioica extracts and cancer types. 




Figure 4. Schematic drawing of $U$. dioica anti-cancer effects. Each $U$. dioica extract and its effects are identified using different color codes. The dashed arrows denote the results obtained with whole extracts; the solid arrows indicate the specific molecules isolated from the extracts and their effects. A generic picture of apoptosis signalling, indicating where and how molecules or extracts of $U$. dioica act on the different cellular targets, is included. By different images are specified if these results were observed in-vitro or in-vivo, on specific cancer types. 


\section{Conclusions and Future Perspectives}

Cancer has become the second most frequent cause of death after cardiac diseases and recent analyses provide an increase of its prevalence in the near future. Breast cancer is the second cause of cancer death among women. Currently, a variety of treatments such as chemotherapy, radiotherapy, hormone therapy and surgery, as well as newer nanotechnology and gene silencing therapy, are used in the treatment of cancer, but induce side effects. Hence, the need to develop the most effective anti-cancer therapy with few side effects and high cytotoxicity that will effectively arrest the initiation and progression of the cancer.

In recent years, many researchers have analyzed natural products and low cost drugs for cancer cure and prevent cancer development. Plants are a precious source of anti-cancer agents; the use of plants for cancer treatment is popular in many Asian cultures and today, beneficial compounds from these plants are used in the production of different modern anti-cancer drugs. Recent studies have illustrated that adjuvant therapy with natural products could help to prevent the development of cancer, as well as cure and improve the survival rate of patients.

Several studies have shown the anti-cancer properties of $U$. dioica, however, to the best of our knowledge, no previous report has reviewed the effects of $U$. dioica extracts on different cancer cell lines and animal cancer models.

Taken together, the main studies on the anti-cancer ability of $U$. dioica extracts provide a promising chance for the use of $U$. dioica as a nutraceutical food for the prevention and treatment of several cancers, including breast cancer. The various extracts of $U$. dioica tested, in fact, prevent cancerogenesis, kill human cancer cells and inhibit their migration. The extracts were not toxic and differences in the growth of the cancer cells was observed compared to the controls (untreated cancer cells) and normal cells, indicating their safety and a promising strategy to reduce adverse effects and ameliorate the efficacy of cancer chemotherapies.

$U$. dioica may exert biological anti-cancer activities through various mechanisms of actions, including antioxidant and anti-mutagenic properties, induction or inhibition of key processes in cellular metabolism and ability to activate the apoptotic pathways. Most anti-cancer drugs induce apoptosis, as a primary mechanism for inhibition of cell proliferation. The apoptotic effect of $U$. dioica in cancer cell lines and animal models was studied at the cellular and molecular levels. The type of cell death (apoptosis or necrosis) was investigated and the pathways involved in apoptosis induction were demonstrated, by studying the genes and proteins involved in the apoptosis process.

The $U$. dioica extracts contain varied bioactive molecules and the ability of these extracts to treat cancer, is due to those components that inhibit tumor growth and induce the apoptosis pathway.

The principal bioactivity of $U$. dioica was found in lipophilic fractions (e.g., dichloromethane extracts), suggesting that lipophilic compounds are mostly responsible for the anti-cancer actions. From the lipophilic fractions phytosterols, pentacyclic triterpenoids, coumarins, ceramides and hydroxyl fatty acids were isolated. In the hydrophobic extracts of the roots the sterols stigmast-4-en-3-one, stigmasterol and campesterol are present, which inhibited the enzyme activity of $\mathrm{Na}+, \mathrm{K}+$-ATPase in patients' tissues with benign prostatic hyperplasia and may subsequently repress prostate-cell metabolism and proliferation. The hydrophilic fractions (e.g., water, methanol, ethanol extracts) of $U$. dioica also demonstrate a high bioactivity, indicating that even polar active principles are responsible for the anti-cancer activity. The hydrophilic fractions contain isolectins and some polysaccharides. In the polar extracts of the roots the lignans as (+)-neoolivil, (-)-secoisolariciresinol, dehydrodiconiferyl alcohol, isolariciresinol, pinoresinol and 3,4-divanillyltetrahydrofuran are also present.

The most likely explanation for the considerable anti-cancer effect of $U$. dioica is the content of flavonoids and other known molecules and/or still unknown substances. Among the food bioactive molecules of $U$. dioica, the flavonoids are polyphenolic compounds that are able to induce anti-cancer effects through different mechanisms such as anti-oxidant activity, induction of apoptosis, inhibition of cell growth and cell migration. In fact, several plants rich in flavonoids possess disease preventive and 
therapeutic properties and, in particular, the consumption of vegetable and fruit rich in flavonoids is associated with reduced cancer risk.

Therefore, $U$. dioica may be used as a nutraceutical food bioactive in cancer treatment to prevent or reduce cancer without presenting the side effects of current anti-cancer treatments.

However, the effects observed could be caused by several molecules and, probably, molecules that have not yet been identified. Further studies are required to isolate and characterize the pure bioactive molecules in this plant to better understand its multiple anti-cancer actions and to explore these potentials in the fight against human cancers.

Author Contributions: Conceptualization, S.E.; software, R.R.; writing一original draft preparation, S.E., P.V.P. and A.B.; writing-review and editing, S.E., R.R. and A.B.; supervision, S.E., P.V.P., A.D.M. and C.I.

Funding: This research received no external funding.

Acknowledgments: This work was supported by University of Campania "Luigi Vanvitelli" and "Progetti per la ricerca oncologica della Regione Campania", Grant: I-Cure. The authors thank Angela Chambery for helpful discussions, Giuseppina Caraglia for english eding, Angela Giojelli and Marco Mammucari for careful support. This article is dedicated to the memory of Marco Esposito for his humanity and scientific competence.

Conflicts of Interest: The authors declare no conflicts of interest.

\section{References}

1. Wildman, R.E.C.; Wildman, R.; Wallace, T.C. Handbook of Nutraceuticals and Functional Foods; CRC Press: Boca Raton, FL, USA, 2016.

2. Angela, M.; Meireles, A. Extracting Bioactive Compounds for Food Products: Theory and Applications; CRC Press: Boca Raton, FL, USA, 2008.

3. Kavalali, G.M. Urtica Therapeutic and Nutritional Aspects of Stinging Nettles; Taylor \& Francis: London, UK, 2003; Volume 37.

4. Upton, R. Stinging nettles leaf (Urtica dioica L.): Extraordinary vegetable medicine. J. Herb. Med. 2013, 3, 9-38. [CrossRef]

5. Ahmed, K.K.M.; Parsuraman, S. Urtica dioica L., (Urticaceae): A Stinging Nettle. Syst. Rev. Pharm. 2014, 5, 6-8. [CrossRef]

6. Oliver, F.; Amon, E.U.; Breathnach, A.; Francis, D.M.; Sarathchandra, P.; Black, A.K.; Greaves, M.W. Contact urticaria due to the common stinging nettle (Urtica dioica)—Histological, ultrastructural and pharmacological studies. Clin. Exp. Dermatol. 1991, 16, 1-7. [CrossRef] [PubMed]

7. Di Virgilio, N.; Papazoglou, E.; Jankauskiene, Z.; Lonardo, S.; Praczyk, M.; Wielgusz, K. The potential of stinging nettle (Urtica dioica L.) as a crop with multiple uses. Ind. Crops Prod. 2015, 68, 42-49. [CrossRef]

8. Law, B.A.; Tamime, A.I. Technology of Cheese Making, 2nd ed.; Wiley-Blackwell: London, UK, 2010; p. 512.

9. Rutto, L.K.; Xu, Y.; Ramirez, E.; Brandt, M. Mineral Properties and Dietary Value of Raw and Processed Stinging Nettle (Urtica dioica L.). Int. J. Food Sci. 2013, 2013, 857120. [CrossRef] [PubMed]

10. Rafajlovska, V.; Rizova, V.; Djarmati, Z.; Tesevic, V.; Cvetkov, L. Contents of fatty acids in stinging nettle extracts (Urtica dioica L.) obtained with supercritical carbon dioxide. Acta Pharm. 2001, 51, 45-51.

11. Đurović, S.; Zekovic, Z.; Šorgić, S.; Popov, S.; Vujanović, M.; Radojković, M. Fatty acid profile of stinging nettle leaves: Application of modern analytical procedures for sample preparation and analysis. Anal. Methods 2018, 10, 1080-1087. [CrossRef]

12. D'Abrosca, B.; Ciaramella, V.; Graziani, V.; Papaccio, F.; Della Corte, C.M.; Potenza, N.; Fiorentino, A.; Ciardiello, F.; Morgillo, F. Urtica dioica L. inhibits proliferation and enhances cisplatin cytotoxicity in NSCLC cells via Endoplasmic Reticulum-stress mediated apoptosis. Sci. Rep. 2019, 9, 4986. [CrossRef]

13. Adhikari, B.M.; Bajracharya, A.; Shrestha, A.K. Comparison of nutritional properties of Stinging nettle (Urtica dioica) flour with wheat and barley flours. Food Sci. Nutr. 2016, 4, 119-124. [CrossRef]

14. Farag, M.A.; Weigend, M.; Luebert, F.; Brokamp, G.; Wessjohann, L.A. Phytochemical, phylogenetic, and anti-inflammatory evaluation of 43 Urtica accessions (stinging nettle) based on UPLC-Q-TOF-MS metabolomic profiles. Phytochemistry 2013, 96, 170-183. [CrossRef]

15. Yan, X.G. New chemical constituents of roots of Urtica triangularis HAND-MASS. Chem. Pharm. Bull. 2008, 56, 1463-1465. [CrossRef] [PubMed] 
16. Đurovic, S.; Pavlic, B.; Šorgic, S.; Popov, S.; Savic, S.; Pertonijevic, M.; Radojkovic, M.; Cvetanovic, A.; Zekovic, Z. Chemical composition of stinging nettle leaves obtained by different analytical approaches. J. Funct. Food. 2017, 32, 18-26. [CrossRef]

17. Orčić, D.; Francišković, M.; Bekvalac, K.; Svirčev, E.; Beara, I.; Lesjak, M.; Mimica-Dukić, N. Quantitative determination of plant phenolics in Urtica dioica extracts by high-performance liquid chromatography coupled with tandem mass spectrometric detection. Food Chem. 2014, 143, 48-53. [CrossRef] [PubMed]

18. Otles, S.; Yalcin, B. Phenolic compounds analysis of root, stalk, and leaves of nettle. Sci. World J. 2012, 2012, 564367. [CrossRef] [PubMed]

19. Pinelli, P.; Ieri, F.; Vignolini, P.; Bacci, L.; Baronti, S.; Romani, A. Extraction and HPLC analysis of phenolic compounds in leaves, stalks, and textile fibers of Urtica dioica L. J. Agric. Food Chem. 2008, 56, 9127-9132. [CrossRef] [PubMed]

20. Krauss, R.; Spitteler, G. Phenolic compounds from roots of Urtica dioica. Phytochemistry 1990, 29, 1653-1659. [CrossRef]

21. Grevsen, K.; Frette, X.C.; Christensen, L.P. Concentration and composition of flavonol glycosides and phenolic acids in aerial parts of stinging nettle (Urtica dioica L.) are affected by nitrogen fertilization and by harvest time. Eur. J. Hortic. Sci. 2008, 73, 20-27.

22. Chaurasia, N.; Wichtl, M. Flavonol Glycosides from Urtica dioica. Planta Med. 1987, 53, 432-434. [CrossRef]

23. Guil-Guerrero, J.L.; Rebolloso-Fuentes, M.M.; Isasa, M.E.T. Fatty acids and carotenoids from Stinging Nettle (Urtica dioica L.). J. Food Compos. Anal. 2003, 16, 111-119. [CrossRef]

24. Hirano, T.; Homma, M.; Oka, K. Effects of stinging nettle root extracts and their steroidal components on the $\mathrm{Na}+, \mathrm{K}+$-ATPase of the benign prostatic hyperplasia. Planta Med. 1994, 60, 30-33. [CrossRef]

25. Chaurasia, N.; Wichtl, M. Sterols and Steryl Glycosides from Urtica dioica. J. Nat. Prod. 1987, 50, 881-885. [CrossRef]

26. Sajfrtová, M.; Sovova, H.; Opletal, L.; Bártlová, M. Near-critical extraction of b-sitosterol and scopoletin from stinging nettle roots. J. Supercrit. Fluid 2005, 35, 111-118. [CrossRef]

27. Carvalho, A.R.; Costab, G.; Figueirinha, A.; Liberal, J.; Prior, J.A.V.; Lopes, M.C.; Cruz, M.T.; Batista, M.T. Urtica spp.: Phenolic composition, safety, antioxidant and anti-inflammatory activities. Food Res. Int. 2017, 99, 485-494. [CrossRef] [PubMed]

28. Lapinskaya, E.S.; Kopytko, Y. Composition of the lipophilic fraction of stinging nettle (Urtica dioica L. and U. urens L.) homeopathic matrix tinctures. Pharm. Chem. J. 2008, 42, 699-702. [CrossRef]

29. Di Maro, A.; Pacifico, S.; Fiorentino, A.; Galasso, S.; Gallicchio, M.; Guida, V.; Severino, V.; Monaco, P.; Parente, A. Raviscanina wild asparagus (Asparagus acutifolius L.): A nutritionally valuable crop with antioxidant and antiproliferative properties. Food Res. Int. 2013, 53, 180-188. [CrossRef]

30. Pacifico, S.; Galasso, S.; Piccolella, S.; Kretschmer, N.; Pan, S.; Marciano, S.; Bauer, R.; Monaco, P. Seasonal variation in phenolic composition and antioxidant and anti-inflammatory activities of Calamintha nepeta (L.) Savi. Food Res. Int. 2015, 69, 121-132. [CrossRef]

31. Pacifico, S.; Piccolella, S.; Nocera, P.; Tranquillo, E.; Dal Poggetto, F.; Catauro, M. New insights into phenol and polyphenol composition of Stevia rebaudiana leaves. J. Pharm. Biomed. Anal. 2019, 163, 45-57. [CrossRef] [PubMed]

32. Del Rio, D.; Rodriguez-Mateos, A.; Spencer, J.P.; Tognolini, M.; Borges, G.; Crozier, A. Dietary (poly)phenolics in human health: Structures, bioavailability, and evidence of protective effects against chronic diseases. Antioxid. Redox Signal. 2013, 18, 1818-1892. [CrossRef] [PubMed]

33. Pacifico, S.; Piccolella, S. Plant-Derived Polyphenols: A Chemopreventive and Chemoprotectant Worth-Exploring Resource in Toxicology. In Advances in Molecular Toxicology; Fishbein, J.C., Heilman, J.M., Eds.; Elsevier: Amsterdam, The Netherlands, 2015; pp. 161-214.

34. Spina, M.; Cuccioloni, M.; Sparapani, L.; Acciarri, S.; Eleuteri, A.M.; Fioretti, E.; Angeletti, M. Comparative evaluation of flavonoid content in assessing quality of wild and cultivated vegetables for human consumption. J. Sci. Food Agric. 2008, 88, 294-304. [CrossRef]

35. Akbay, P.; Basaran, A.A.; Undeger, U.; Basaran, N. In vitro immunomodulatory activity of flavonoid glycosides from Urtica dioica L. Phytother. Res. 2003, 17, 34-37. [CrossRef] [PubMed]

36. Gülçin, I.; Küfrevioglu, O.I.; Oktay, M.; Büyükokuroglu, M.E. Antioxidant, antimicrobial, antiulcer and analgesic activities of nettle (Urtica dioica L.). J. Ethnopharmacol. 2004, 90, 205-215. [CrossRef] [PubMed] 
37. Chrubasik, J.E.; Roufogalis, B.D.; Wagner, H.; Chrubasik, S.A. A comprehensive review on nettle effect and efficacy profiles, Part I: Herba urticae. Phytomedicine 2007, 14, 423-435. [CrossRef] [PubMed]

38. Chrubasik, J.E.; Roufogalis, B.D.; Wagner, H.; Chrubasik, S. A comprehensive review on the stinging nettle effect and efficacy profiles. Part II: Urticae radix. Phytomedicine 2007, 14, 568-579. [CrossRef] [PubMed]

39. El Haouari, M.; Rosado, J.A. Phytochemical, Anti-diabetic and Cardiovascular Properties of Urtica dioica L. (Urticaceae): A Review. Mini Rev. Med. Chem. 2019, 19, 63-71. [CrossRef] [PubMed]

40. Zemmouri, H.; Sekiou, O.; Ammar, S.; El Feki, A.; Bouaziz, M.; Messarah, M.; Boumendjel, A. Urtica dioica attenuates ovalbumin-induced inflammation and lipid peroxidation of lung tissues in rat asthma model. Pharm. Biol. 2017, 55, 1561-1568. [CrossRef]

41. Schulze-Tanzil, G. Effects of the antirheumatic remedy hox alpha-a new stinging nettle leaf extract-on matrix metalloproteinases in human chondrocytes in vitro. Histol. Histopathol. 2002, 17, 477-485. [CrossRef] [PubMed]

42. Riehemann, K.; Behnke, B.; Schulze-Osthoff, K. Plant extracts from stinging nettle (Urtica dioica), an antirheumatic remedy, inhibit the proinflammatory transcription factor NF-kappaB. FEBS Lett. 1999, 442, 89-94. [CrossRef]

43. Bisht, R.; Joshi, B.C.; Kalia, A.N.; Prakash, A. Antioxidant-Rich Fraction of Urtica dioica Mediated Rescue of Striatal Mito-Oxidative Damage in MPTP-Induced Behavioral, Cellular, and Neurochemical Alterations in Rats. Mol. Neurobiol. 2017, 54, 5632-5645. [CrossRef]

44. Di Sotto, A.; Mazzanti, G.; Savickiene, N.; Staršelskytè, R.; Baksenskaite, V.; Di Giacomo, S.; Vitalone, A. Antimutagenic and antioxidant activity of a protein fraction from aerial parts of Urtica dioica. Pharm. Biol. 2015, 53, 935-938. [CrossRef]

45. Fattahi, S.; Ardekani, A.M.; Zabihi, E.; Abedian, Z.; Mostafazadeh, A.; Pourbagher, R.; Akhavan-Niaki, H. Antioxidant and apoptotic effects of an aqueous extract of Urtica dioica on the MCF-7 human breast cancer cell line. Asian Pac. J. Cancer Prev. 2013, 14, 5317-5323. [CrossRef]

46. Kukric, Z.; Topalić-Trivunović, L.; Kukavica, B.; Matos, S.; Pavicic, S.; Boroja, M.; Savić, A. Characterization of antioxidant and antimicrobial activities of nettle leaves (Urtica dioica L.). Acta Period. Technol. 2012, 43, 257-272. [CrossRef]

47. Ghaima, K.K.; Hashim, N.M.; Ali, S.A. Antibacterial and antioxidant activities of ethyl acetate extract of nettle (Urtica dioica) and dandelion (Taraxacum officinale). J. Pharm. Sci. 2013, 3, 96-99.

48. Kregiel, D.; Pawlikowska, E.; Antolak, H. Urtica spp.: Ordinary Plants with Extraordinary Properties. Molecules 2018, 23, 1664. [CrossRef] [PubMed]

49. Batool, R.; Salahuddin, H.; Mahmood, T.; Ismail, M. Study of anticancer and antibacterial activities of Foeniculum vulgare, Justicia adhatoda and Urtica dioica as natural curatives. Cell. Mol. Biol. 2017, 63, 109-114. [CrossRef] [PubMed]

50. Ranjbari, A.; Azarbayjani, M.A.; Yusof, A.; Halim Mokhtar, A.; Akbarzadeh, S.; Ibrahim, M.Y.; Tarverdizadeh, B.; Farzadinia, P.; Hajiaghaee, R.; Dehghan, F. In vivo and in vitro evaluation of the effects of Urtica dioica and swimming activity on diabetic factors and pancreatic beta cells. BMC Complement. Altern. Med. 2016, 16, 101. [CrossRef]

51. Domola, M.S.; Vu, V.; Robson-Doucette, C.A.; Sweeney, G.; Wheeler, M.B. Insulin mimetics in Urtica dioica: Structural and computational analyses of Urtica dioica extracts. Phytother. Res. 2010, 24 (Suppl. 2), S175-S182. [CrossRef]

52. Francišković, M.; Gonzalez-Pérez, R.; Orčić, D.; Sánchez de Medina, F.; Martínez-Augustin, O.; Svirčev, E.; Simin, N.; Mimica-Dukić, N. Chemical Composition and Immuno-Modulatory Effects of Urtica dioica L. (Stinging Nettle) Extracts. Phytother. Res. 2017, 31, 1183-1191. [CrossRef]

53. Siegel, R.L.; Miller, K.D.; Jemal, A. Cancer statistics, 2016. CA Cancer J. Clin. 2016, 66, 7-30. [CrossRef]

54. Torre, L.A.; Siegel, R.L.; Ward, E.M.; Jemal, A. Global Cancer Incidence and Mortality Rates and Trends-An Update. Cancer Epidemiol. Biomark. Prev. 2016, 25, 16-27. [CrossRef]

55. Ferlay, J.; Soerjomataram, I.; Dikshit, R.; Eser, S.; Mathers, C.; Rebelo, M.; Parkin, D.M.; Forman, D.; Bray, F. Cancer incidence and mortality worldwide: Sources, methods and major patterns in GLOBOCAN 2012. Int. J. Cancer 2015, 136, E359-E386. [CrossRef]

56. Gelmann, E.P.; Sawyers, C.L.; Rauscher, F.J.I. Molecular Oncology: Causes of Cancer and Targets for Treatment; Cambridge University Press: Cambridge, UK, 2013. 
57. Steward, W.P.; Brown, K. Cancer chemoprevention: A rapidly evolving field. Br. J. Cancer 2013, 109 , 1-7. [CrossRef]

58. Kucuk, O. New opportunities in chemoprevention research. Cancer Investig. 2002, 20, 237-245. [CrossRef]

59. Kocasli, S.; Demircan, Z. Herbal product use by the cancer patients in both the pre and post surgery periods and during chemotherapy. Afr. J. Tradit. Complement. Altern. Med. 2017, 14, 325-333. [CrossRef]

60. Liao, G.S.; Apaya, M.K.; Shyur, L.F. Herbal medicine and acupuncture for breast cancer palliative care and adjuvant therapy. Evid. Based Complement. Altern. Med. 2013, 2013, 437948. [CrossRef]

61. Nahata, A.; Saxena, A.; Suri, N.; Saxena, A.K.; Dixit, V.K. Sphaeranthus indicus induces apoptosis through mitochondrial-dependent pathway in HL-60 cells and exerts cytotoxic potential on several human cancer cell lines. Integr. Cancer Ther. 2013, 12, 236-247. [CrossRef]

62. Olaku, O.; White, J.D. Herbal therapy use by cancer patients: A literature review on case reports. Eur. J. Cancer 2011, 47, 508-514. [CrossRef]

63. Balunas, M.J.; Kinghorn, A.D. Drug discovery from medicinal plants. Life Sci. 2005, 78, 431-441. [CrossRef]

64. D'Incalci, M.; Steward, W.P.; Gescher, A.J. Use of cancer chemopreventive phytochemicals as antineoplastic agents. Lancet Oncol. 2005, 6, 899-904. [CrossRef]

65. Paterson, I.; Anderson, E.A. The renaissance of natural products as drug candidates. Science 2005, 310. [CrossRef]

66. Smit, A.J. Medicinal and pharmaceutical uses of seaweed natural products: A review. J. Appl. Phycol. 2004, 16. [CrossRef]

67. Jung Park, E.; Pezzuto, J.M. Botanicals in cancer chemoprevention. Cancer Metastasis Rev. 2002, 21. [CrossRef]

68. Mann, J. Natural products in cancer chemotherapy: Past, present and future. Nat. Rev. Cancer 2002, 2. [CrossRef]

69. Kandaswami, C.; Kanadaswami, C.; Lee, L.T.; Lee, P.P.; Hwang, J.J.; Ke, F.C.; Huang, Y.T.; Lee, M.T. The antitumor activities of flavonoids. In Vivo 2005, 19, 895-909.

70. Kawaii, S.; Tomono, Y.; Katase, E.; Ogawa, K.; Yano, M. Antiproliferative activity of flavonoids on several cancer cell lines. Biosci. Biotechnol. Biochem. 1999, 63. [CrossRef]

71. Cragg, G.M.; Newman, D.J. Plants as a source of anti-cancer agents. J. Ethnopharmacol. 2005, 100, 72-79. [CrossRef]

72. Jin, Z.; El-Deiry, W.S. Overview of cell death signaling pathways. Cancer Biol. Ther. 2005, 4, 139-163. [CrossRef]

73. Ciniglia, C.; Mastrobuoni, F.; Scortichini, M.; Petriccione, M. Oxidative damage and cell-programmed death induced in Zea mays L. by allelochemical stress. Ecotoxicology 2015, 24, 926-937. [CrossRef]

74. Florea, A.M.; Busselberg, D. Cisplatin as an anti-tumor drug: Cellular mechanisms of activity, drug resistance and induced side effects. Cancers 2011, 3, 1351. [CrossRef]

75. Siddik, Z.H. Cisplatin: Mode of cytotoxic action and molecular basis of resistance. Oncogene $2003,22$. [CrossRef]

76. Ozkol,H.; Musa, D.; Tuluce, Y.; Koyuncu, I.; Asadi-Samani, M.; Rafieian-Kopaei, M.; Lorigooini, Z.; Shirzad, H. Ameliorative influence of Urtica dioica L against cisplatin-induced toxicity in mice bearing Ehrlich ascites carcinoma. Drug Chem. Toxicol. 2012, 35, 251-257. [CrossRef]

77. Nollet, L.M.L.; Gutierrez-Uribe, J.A. Phenolic Compounds in Food: Characterization and Analysis; CRC Press: Boca Raton, FL, USA, 2018.

78. Faramarzi, S.; Pacifico, S.; Yadollahi, A.; Lettieri, A.; Nocera, P.; Piccolella, S. Red-fleshed Apples: Old Autochthonous Fruits as a Novel Source of Anthocyanin Antioxidants. Plant Foods Hum. Nutr. 2015, 70, 324-330. [CrossRef]

79. Keskin-Šašic, I.; Tahirovic, A.; Top`cagic, A.; Klepo, L.; Salihovic, M.; Ibragic, S.; Toromanovi, J.; Ajanovic, A.; Velispahic, E. Total phenolic content and antioxidant capacity of fruit juices. Bull. Chem. Technol. Bosnia Herzeg. 2012, 39, 25-28.

80. Wang, C.; Yu, J.; Wang, H.; Zhang, J.; Wu, N. Lipid peroxidation and altered anti-oxidant status in breast adenocarcinoma patients. Drug Res. 2014, 64, 690-692. [CrossRef]

81. Ray, G.; Batra, S.; Shukla, N.K.; Deo, S.; Raina, V.; Ashok, S.; Husain, S.A. Lipid peroxidation, free radical production and antioxidant status in breast cancer. Breast Cancer Res. Treat. 2000, 59, 163-170. [CrossRef]

82. Khanzode, S.S.; Muddeshwar, M.G.; Khanzode, S.D.; Dakhale, G.N. Antioxidant Enzymes and Lipid Peroxidation in Different Stages of Breast Cancer. Free Radic. Res. 2004, 38, 81-85. [CrossRef] 
83. Benz, E.J.; Nathan, D.G.; Amaravadi, R.K.; Danial, N.N. Targeting the cell death-survival equation. Clin. Cancer Res. 2007, 13, 7250-7253. [CrossRef]

84. Taraphdar, A.K.; Roy, M.; Bhattacharya, R.K. Natural products as inducers of apoptosis: Implication for cancer therapy and prevention. Curr. Sci. 2001, 80, 1387-1396.

85. Wagner, H.; Willer, F.; Samtleben, R.; Boos, G. Search for the antiprostatic principle of stinging nettle (Urtica dioica) roots. Phytomedicine 1994, 1, 213-224. [CrossRef]

86. Ghasemi, S.; Moradzadeh, M.; Mousavi, S.H.; Sadeghnia, H.R. Cytotoxic effects of Urtica dioica radix on human colon (HT29) and gastric (MKN45) cancer cells mediated through oxidative and apoptotic mechanisms. Cell. Mol. Biol. 2016, 62, 90-96.

87. Mohammadi, A.; Mansoori, B.; Aghapour, M.; Baradaran, P.C.; Shajari, N.; Davudian, S.; Salehi, S.; Baradaran, B. The Herbal Medicine Utrica Dioica Inhibits Proliferation of Colorectal Cancer Cell Line by Inducing Apoptosis and Arrest at the G2/M Phase. J. Gastrointest. Cancer 2016, 47, 187-195. [CrossRef]

88. Lichius, J.J.; Muth, C. The inhibiting effects of Urtica dioica root extracts on experimentally induced prostatic hyperplasia in the mouse. Planta Med. 1997, 63, 307-310. [CrossRef]

89. Konrad, L.; Müller, H.H.; Lenz, C.; Laubinger, H.; Aumüller, G.; Lichius, J.J. Antiproliferative effect on human prostate cancer cells by a stinging nettle root (Urtica dioica) extract. Planta Med. 2000, 66, 44-47. [CrossRef]

90. Durak, I.; Biri, H.; Devrim, E.; Sözen, S.; Avci, A. Aqueous extract of Urtica dioica makes significant inhibition on adenosine deaminase activity in prostate tissue from patients with prostate cancer. Cancer Biol. Ther. 2004, 3, 855-857. [CrossRef]

91. Nahata, A.; Dixit, V.K. Ameliorative effects of stinging nettle (Urtica dioica) on testosterone-induced prostatic hyperplasia in rats. Andrologia 2012, 44 (Suppl. 1), 396-409. [CrossRef]

92. Mohammadi, A.; Mansoori, B.; Aghapour, M.; Baradaran, B. Urtica dioica dichloromethane extract induce apoptosis from intrinsic pathway on human prostate cancer cells (PC3). Cell. Mol. Biol. 2016, 62, 78-83.

93. Wang, G.; Reed, E.; Li, Q.Q. Molecular basis of cellular response to cisplatin chemotherapy in non-small cell lung cancer (Review). Oncol. Rep. 2004, 12. [CrossRef]

94. Abdelrahim, M.; Newman, K.; Vanderlaag, K.; Samudio, I.; Safe, S. 3, 3'-Diindolylmethane (DIM) and its derivatives induce apoptosis in pancreatic cancer cells through endoplasmic reticulum stress-dependent upregulation of DR5. Carcinogenesis 2006, 27. [CrossRef]

95. Oyadomari, S.; Mori, M. Roles of CHOP/GADD153 in endoplasmic reticulum stress. Cell Death Differ. 2004, 11. [CrossRef]

96. Yamaguchi, H.; Wang, H.G. CHOP is involved in endoplasmic reticulum stress-induced apoptosis by enhancing DR5 expression in human carcinoma cells. J. Biol. Chem. 2004, 279. [CrossRef]

97. Kelley, S.K.; Ashkenazi, A. Targeting death receptors in cancer with Apo2L/TRAIL. Curr. Opin. Pharmacol. 2004, 4. [CrossRef]

98. Randa, A.; Kamel, S. Bioactive oxylipins from the endophyte Khuskia oryzae isolated from the medicinal plant Bidens alba. Eur. J. Biomed. Pharm. Sci. 2015, 2, 630-639.

99. Romano, G. Design and synthesis of pro-apoptotic compounds inspired by diatom oxylipins. Mar. Drugs 2013, 11, 4527. [CrossRef]

100. Gerwick, W.H. Biologically active oxylipins from seaweeds. Hydrobiologia 1993, 260-261. [CrossRef]

101. Hwang, J.H.; Voortman, J.; Giovannetti, E.; Steinberg, S.M.; Leon, L.G.; Kim, Y.T.; Funel, N.; Park, J.K.; Kim, M.A.; Kang, G.H.; et al. Identification of microRNA-21 as a biomarker for chemoresistance and clinical outcome following adjuvant therapy in resectable pancreatic cancer. PLoS ONE 2010, 5, e10630. [CrossRef]

102. Verpoorte, R.; Choi, Y.H.; Kim, H.K. NMR-based metabolomics at work in phytochemistry. Phytochem. Rev. 2007, 6. [CrossRef]

103. Gabbs, M.; Leng, S.; Devassy, J.G.; Monirujjaman, M.; Aukema, H.M. Advances in Our Understanding of Oxylipins Derived from Dietary PUFAs. Adv. Nutr. 2015, 6, 513-540. [CrossRef]

104. Baldin, V.; Lukas, J.; Marcote, M.J.; Pagano, M.; Draetta, G. Cyclin D1 is a nuclear protein required for cell cycle progression in G1. Genes Dev 1993, 7, 812-821. [CrossRef]

105. Altiok, N.; Mezzadra, H.; Patel, P.; Koyuturk, M.; Altiok, S. A plant oxylipin, 12-oxo-phytodienoic acid, inhibits proliferation of human breast cancer cells by targeting cyclin D1. Breast Cancer Res. Treat. 2008, 109. [CrossRef] 
106. Does, M.P.; Ng, D.K.; Dekker, H.L.; Peumans, W.J.; Houterman, P.M.; Van Damme, E.J.; Cornelissen, B.J. Characterization of Urtica dioica agglutinin isolectins and the encoding gene family. Plant Mol. Biol. 1999, 39, 335-347. [CrossRef]

107. Wagner, H.; Geiger, W.N.; Boos, G.; Samtleben, R. Studies on the binding of Urtica dioica agglutinin (UDA) and other lectins in an in vitro epidermal growth factor receptor test. Phytomedicine 1995, 1, 287-290. [CrossRef]

108. Steers, W.D. 5alpha-reductase activity in the prostate. Urology 2001, 58, 17-24. [CrossRef]

109. Valitova, J.N.; Sulkarnayeva, A.G.; Minibayeva, F.V. Plant Sterols: Diversity, Biosynthesis, and Physiological Functions. Biochemistry 2016, 81, 819-834. [CrossRef]

110. Berges, R.R.; Windeler, J.; Trampisch, H.J.; Senge, T. Randomised, placebo-controlled, double-blind clinical trial of beta-sitosterol in patients with benign prostatic hyperplasia. Beta-sitosterol Study Group. Lancet 1995, 345, 1529-1532. [CrossRef]

111. Wilt, T.J.; MacDonald, R.; Ishani, A. beta-sitosterol for the treatment of benign prostatic hyperplasia: A systematic review. BJU Int. 1999, 83, 976-983. [CrossRef]

112. Bourgaud, F.; Hehn, A.; Larbat, R.; Doerper, S.; Gontier, E.; Kellner, S.; Matern, U. Biosynthesis of coumarins in plants: A major pathway still to be unravelled for cytochrome P450 enzymes. Phytochem. Rev. 2006, 5, 293-308. [CrossRef]

113. Ding, Z.; Dai, Y.; Hao, H.; Pan, R.; Yao, X.; Wang, Z. Anti-inflammatory effects of scopoletin and underlying mechanisms. Pharm. Biol. 2008, 46, 854-860. [CrossRef]

114. Liu, X.L.; Zhang, L.; Fu, X.L.; Chen, K.; Qian, B.C. Effect of scopoletin on PC3 cell proliferation and apoptosis. Acta Pharmacol. Sin. 2001, 22, 929-933.

115. Kohler, B.A.; Sherman, R.L.; Howlader, N.; Jemal, A.; Ryerson, A.B.; Henry, K.A.; Boscoe, F.P.; Cronin, K.A.; Lake, A.; Noone, A.-M.; et al. Annual Report to the Nation on the Status of Cancer, 1975-2011, Featuring Incidence of Breast Cancer Subtypes by Race/Ethnicity, Poverty, and State. JNCI J. Natl. Cancer Inst. 2015, 107. [CrossRef]

116. DeSantis, C.; Ma, J.; Bryan, L.; Jemal, A. Breast cancer statistics, 2013. CA Cancer J. Clin. 2014, 64, 52-62. [CrossRef]

117. Sharma, G.N.; Dave, R.; Sanadya, J.; Sharma, P.; Sharma, K.K. Various types and management of breast cancer: An overview. J. Adv. Pharm. Technol. Res. 2010, 1, 109-126.

118. Nounou, M.I.; ElAmrawy, F.; Ahmed, N.; Abdelraouf, K.; Goda, S.; Syed-Sha-Qhattal, H. Breast Cancer: Conventional Diagnosis and Treatment Modalities and Recent Patents and Technologies. Breast Cancer 2015, 9, 17-34. [CrossRef]

119. Mitra, S.; Dash, R. Natural Products for the Management and Prevention of Breast Cancer. Evid. Based Complement. Altern. Med. 2018, 2018, 8324696. [CrossRef]

120. Lin, B.; Kolluri, S.K.; Lin, F.; Liu, W.; Han, Y.H.; Cao, X.; Dawson, M.I.; Reed, J.C.; Zhang, X.K. Conversion of $\mathrm{Bcl}-2$ from protector to killer by interaction with nuclear orphan receptor Nur77/TR3. Cell 2004, 116, 527-540. [CrossRef]

121. Fattahi, S.; Ghadami, E.; Asouri, M.; Motevalizadeh Ardekanid, A.; Akhavan-Niaki, H. Urtica dioica inhibits cell growth and induces apoptosis by targeting Ornithine decarboxylase and Adenosine deaminase as key regulatory enzymes in adenosine and polyamines homeostasis in human breast cancer cell lines. Cell. Mol. Biol. 2018, 64, 97-102. [CrossRef]

122. Tullo, A.; Mastropasqua, G.; Bourdon, J.C.; Centonze, P.; Gostissa, M.; Costanzo, A.; Levrero, M.; Del Sal, G.; Saccone, C.; Sbisà, E. Adenosine deaminase, a key enzyme in DNA precursors control, is a new p73 target. Oncogene 2003, 22, 8738-8748. [CrossRef]

123. Zhu, Q.; Jin, L.; Casero, R.A.; Davidson, N.E.; Huang, Y. Role of ornithine decarboxylase in regulation of estrogen receptor alpha expression and growth in human breast cancer cells. Breast Cancer Res. Treat. 2012, 136, 57-66. [CrossRef]

124. Apasov, S.G.; Blackburn, M.R.; Kellems, R.E.; Smith, P.T.; Sitkovsky, M.V. Adenosine deaminase deficiency increases thymic apoptosis and causes defective T cell receptor signaling. J. Clin. Investig. 2001, 108, 131-141. [CrossRef]

125. Nowotarski, S.L.; Woster, P.M.; Casero, R.A. Polyamines and cancer: Implications for chemotherapy and chemoprevention. Expert Rev. Mol. Med. 2013, 15, e3. [CrossRef]

126. Gerner, E.W.; Meyskens, F.L. Polyamines and cancer: Old molecules, new understanding. Nat. Rev. Cancer 2004, 4, 781-792. [CrossRef] 
127. Jalili, C.; Salahshoor, M.R.; Yousefi, D.; Khazaei, M.; Shabanizadeh Darehdori, A.; Mokhtari, T. Morphometric and Hormonal Study of the Effect of Utrica diocia Extract on Mammary Glands in Rats. Int. J. Morphol. 2015, 983-987. [CrossRef]

128. Abu-Dahab, R.; Afifi, F. Antiproliferative activity of selected medicinal plants of Jordan against a breast adenocarcinoma cell line (MCF7). Sci. Pharm. 2007, 75. [CrossRef]

129. Mohammadi, A.; Mansoori, B.; Goldar, S.; Shanehbandi, D.; Khaze, V.; Mohammadnejad, L.; Baghbani, E.; Baradaran, B. Effects of Urtica dioica dichloromethane extract on cell apoptosis and related gene expression in human breast cancer cell line (MDA-MB-468). Cell. Mol. Biol. 2016, 62, 62-67.

130. Mohammadi, A.; Mansoori, B.; Aghapour, M.; Shirjang, S.; Nami, S.; Baradaran, B. The Urtica dioica extract enhances sensitivity of paclitaxel drug to MDA-MB-468 breast cancer cells. Biomed. Pharmacother. 2016, 83, 835-842. [CrossRef]

131. Mansoori, B.; Mohammadi, A.; Hashemzadeh, S.; Shirjang, S.; Baradaran, A.; Asadi, M.; Doustvandi, M.A.; Baradaran, B. Urtica dioica extract suppresses miR-21 and metastasis-related genes in breast cancer. Biomed. Pharmacother. 2017, 93, 95-102. [CrossRef]

132. Mohammadi, A.; Mansoori, B.; Baradaran, P.C.; Khaze, V.; Aghapour, M.; Farhadi, M.; Baradaran, B. Urtica dioica Extract Inhibits Proliferation and Induces Apoptosis and Related Gene Expression of Breast Cancer Cells In Vitro and In Vivo. Clin. Breast Cancer 2017, 17, 463-470. [CrossRef]

133. Telo, S.; Halifeoglu, I.; Ozercan, I.H. Effects of Stinging Nettle (Urtica dioica L.,) on Antioxidant Enzyme Activities in Rat Model of Mammary Gland Cancer. Iran. J. Pharm. Res. 2017, 16, 164-170.

134. Mekhail, T.M.; Markman, M. Paclitaxel in cancer therapy. Expert Opin. Pharmacother. 2002, 3, 755-766.

135. Yarrow, J.C.; Perlman, Z.E.; Westwood, N.J.; Mitchison, T.J. A high-throughput cell migration assay using scratch wound healing, a comparison of image-based readout methods. BMC Biotechnol. 2004, 4, 21. [CrossRef]

136. Savary, K.; Caglayan, D.; Caja, L.; Tzavlaki, K.; Bin Nayeem, S.; Bergström, T.; Jiang, Y.; Uhrbom, L.; Forsberg-Nilsson, K.; Westermark, B.; et al. Snail depletes the tumorigenic potential of glioblastoma. Oncogene 2013, 32, 5409. [CrossRef]

137. Waldmann, J.; Feldmann, G.; Slater, E.P.; Langer, P.; Buchholz, M.; Ramaswamy, A.; Saeger, W.; Rothmund, M.; Fendrich, V. Expression of the zinc-finger transcription factor Snail in adrenocortical carcinoma is associated with decreased survival. Br. J. Cancer 2008, 99, 1900-1907. [CrossRef]

138. Batlle, E.; Sancho, E.; Francí, C.; Domínguez, D.; Monfar, M.; Baulida, J.; García De Herreros, A. The transcription factor snail is a repressor of E-cadherin gene expression in epithelial tumour cells. Nat. Cell Biol. 2000, 2, 84-89. [CrossRef]

139. Tran, H.D.; Luitel, K.; Kim, M.; Zhang, K.; Longmore, G.D.; Tran, D.D. Transient SNAIL1 expression is necessary for metastatic competence in breast cancer. Cancer Res. 2014, 74, 6330-6340. [CrossRef]

140. Lin, H.-C.; Cheng, Y.-W.; Hsu, N.-Y. The association of miR-21, HER-2/neu, and PTEN expression and clinical outcome of breast cancer. Cancer Res. 2014, 74 (Suppl. 19), 1470.

141. Liu, Z.L.; Wang, H.; Liu, J.; Wang, Z.X. MicroRNA-21 (miR-21) expression promotes growth, metastasis, and chemo- or radioresistance in non-small cell lung cancer cells by targeting PTEN. Mol. Cell. Biochem. 2013, 372, 35-45. [CrossRef]

142. Cheng, H.; Shi, S.; Cai, X.; Long, J.; Xu, J.; Liu, C.; Yu, X. microRNA signature for human pancreatic cancer invasion and metastasis. Exp. Ther. Med. 2012, 4, 181-187. [CrossRef]

143. Medina, P.P.; Nolde, M.; Slack, F.J. OncomiR addiction in an in vivo model of microRNA-21-induced pre-B-cell lymphoma. Nature 2010, 467, 86-90. [CrossRef]

144. Huang, T.H.; Wu, F.; Loeb, G.B.; Hsu, R.; Heidersbach, A.; Brincat, A.; Horiuchi, D.; Lebbink, R.J.; Mo, Y.Y.; Goga, A.; et al. Up-regulation of miR-21 by HER2/neu signaling promotes cell invasion. J. Biol. Chem. 2009, 284, 18515-18524. [CrossRef]

145. Nicoloso, M.S.; Spizzo, R.; Shimizu, M.; Rossi, S.; Calin, G.A. MicroRNAs-The micro steering wheel of tumour metastases. Nat. Rev. Cancer 2009, 9, 293-302. [CrossRef]

146. He, L.; Hannon, G.J. MicroRNAs: Small RNAs with a big role in gene regulation. Nat. Rev. Genet. 2004, 5, 522-531. [CrossRef]

147. Merdad, A.; Karim, S.; Schulten, H.J.; Dallol, A.; Buhmeida, A.; Al-Thubaity, F.; Gari, M.A.; Chaudhary, A.G.; Abuzenadah, A.M.; Al-Qahtani, M.H. Expression of matrix metalloproteinases (MMPs) in primary human 
breast cancer: MMP-9 as a potential biomarker for cancer invasion and metastasis. Anticancer Res. 2014, 34, 1355-1366.

148. Kokkinos, M.I.; Wafai, R.; Wong, M.K.; Newgreen, D.F.; Thompson, E.W.; Waltham, M. Vimentin and epithelial-mesenchymal transition in human breast cancer-observations in vitro and in vivo. Cells Tissues Organs 2007, 185, 191-203. [CrossRef]

149. Catherine, C.M.; Shaffer, C.V.; Jacqueline, F. A novel CXCR4 pathway is required for migration of metastatic breast cancer cells. Cancer Res. 2015, 75 (Suppl. 15), 4043.

150. Mukherjee, D.; Zhao, J. The Role of chemokine receptor CXCR4 in breast cancer metastasis. Am. J. Cancer Res. 2013, 3, 46-57.

151. Canel, M.; Serrels, A.; Frame, M.C.; Brunton, V.G. E-cadherin-integrin crosstalk in cancer invasion and metastasis. J. Cell Sci. 2013, 126, 393-401. [CrossRef]

152. Thiery, J.P.; Acloque, H.; Huang, R.Y.; Nieto, M.A. Epithelial-mesenchymal transitions in development and disease. Cell 2009, 139, 871-890. [CrossRef]

153. Gansser, D.; Spiteller, G. Aromatase inhibitors from Urtica dioica roots. Planta Med. 1995, 61, 138-140. [CrossRef]

(C) 2019 by the authors. Licensee MDPI, Basel, Switzerland. This article is an open access article distributed under the terms and conditions of the Creative Commons Attribution (CC BY) license (http://creativecommons.org/licenses/by/4.0/). 